Article

\title{
Factors Influencing the Willingness to Pay for Aquaponic Products in a Developed Food Market: A Structural Equation Modeling Approach
}

\author{
Theresa Eichhorn ${ }^{1}$ and Oliver Meixner ${ }^{2, *}$ (i) \\ 1 Institute of Agricultural and Forestry Economics (AFO), Department of Economics and Social Sciences, \\ University of Natural Resources and Life Sciences, 1180 Vienna, Austria; theresa.eichhorn@boku.ac.at \\ 2 Institute of Marketing and Innovation, Department of Economics and Social Sciences, University of Natural \\ Resources and Life Sciences, 1180 Vienna, Austria \\ * Correspondence: oliver.meixner@boku.ac.at
}

Received: 24 March 2020; Accepted: 22 April 2020; Published: 24 April 2020

\begin{abstract}
Even in highly developed food markets, aquaponic products have not yet been successfully introduced. This is particularly surprising, as aquaponics is an excellent example of a sustainable circulation food production system. The purpose of this empirical study was to determine the factors that influence consumers' willingness to pay for aquaponic products. The direct and indirect relationships were tested via Structural Equation Modeling (SEM). Primary data of 315 respondents from Austria were collected. The findings revealed that the willingness to pay for aquaponic products was significantly and directly driven by the purchase intention. As a result, the successful implementation of aquaponics in the market requires the provision of information for consumers. We suggest emphasizing the value of aquaponics as a sustainable food production system, since indirect factors that influence the willingness to pay are (besides the assessment of aquaponics) environmental awareness and green consumption.
\end{abstract}

Keywords: aquaponics; Structural Equation Modeling; consumer behavior; purchase intention; willingness to pay; sustainability; food market

\section{Introduction}

Global food markets are confronted with increasingly scarce resources (fertile soil and water), a growing world population, and a multitude of environmental problems [1,2]. The United Nations (UN) assumes that more than 9.7 billion people will be living on the Earth in 2050 and the population will reach about 11 billion in 2100 [3]. In line with growing prosperity, agricultural production will have to increase by two-thirds by 2050 [4]. To address this problem, scarce resources, such as water and fertile soil, have to be used more efficiently, and a sustainable food production system is needed [5]. Innovative food production systems, such as vertical farming, urban agriculture, and aquaponics, could positively contribute in this respect. Aquaponics is considered to be a sustainable food production system [6-8] that combines fish farming ("aquaculture") and plant cultivation ("hydroponics") in an integrated circulation system that uses the resulting synergy effects [9,10]. The nutrients released by the fish are used by the plants, which, in turn, act as a natural filter (through bacteria) for the water used by the fish [11,12]. Aquaponic systems have a great potential to produce healthy food (fish, vegetables, and herbs) with efficient nutrient utilization and low water consumption. Due to its limited land requirements and sophisticated use of technology, aquaponics can contribute to food security - particularly in urban areas with short value chains [13-15] - but also in rural areas and developing countries $[7,16]$. Compared to conventional agricultural systems, aquaponics requires only 
about $10 \%$ of water depending on climate conditions [17], and pesticides cannot be used within the production system [18].

Over the past ten years, global aquaponic production has increased significantly, especially in North America and Australia, where numerous research reports were published and large aquaponic production plants were put into existence $[19,20]$. However, aquaponics is still in its early stages, and it is not yet a successful business model [10]. In addition, within the European market, the commercialization of aquaponic products is problematic because aquaponic products cannot be certified as organic food in the EU in accordance with the European Commission Regulation (EC) No. 889/2008, paragraph 4, and No. 710/2009, paragraph 11 [21]. In the Austrian food retail sector, the organic share is nine percent. Eggs, milk, and vegetables are most often bought organically [22]. Organic certification could be very beneficial here. Furthermore, Tokunaga et al. [23] have found that organic certification increases the willingness to pay (WTP) and predicts that it will increase the return on investment in aquaponics by about $5 \%$.

The European aquaponics market is in an early stage of development; many new companies are being established in this field, but only a few reach the economically viable minimum production volume [19]. Furthermore, it is not possible to determine how high the break-even price for aquaponic products must be for the plants to be economically viable [24]. This is due to the large number of different systems working in different locations under different conditions [24].

Nevertheless, aquaponics producers need to know whether consumers are prepared to pay more for aquaponic products, as Miličić et al. [21] and Greenfeld et al. [10] have researched. In planning to be able to intervene more specifically in the willingness to pay for future consumers, it is, above all, important to know which factors influence this willingness to pay. For this reason, this paper aims to identify the factors that directly and indirectly influence the willingness to pay (WTP) for aquaponic products. Up until now, no published study seems to explicitly address the drivers of the WTP for aquaponic products. The central research question, therefore, is: which direct and indirect factors influence the willingness to pay for aquaponic products?

To answer the research question, the following hypotheses are tested:

H1: Familiarity with aquaponics (FA) has a positive and significant impact on the willingness to pay (WTP).

H2: Familiarity with aquaponics (FA) has a positive and significant impact on the purchase intention (PI).

H3: Environmental awareness and green consumption (EAGC) have a positive and significant impact on the assessment of aquaponics (AA).

H4: Environmental awareness and green consumption (EAGC) have a positive and significant impact on intention to buy (PI).

H5: Environmental awareness and green consumption (EAGC) have a positive and significant impact on willingness to pay (WTP).

H6: The assessment of aquaponics ( $A A$ ) has a positive and significant impact on the purchase intention (PI).

H7: The assessment of aquaponics ( $A A$ ) has a positive and significant impact on the willingness to pay (WTP).

H8: The purchase intention in favor of aquaponic products (PI) has a positive and significant impact on the willingness to pay (WTP).

We developed a Structural Equation Model (SEM) based on the literature (Chapter 2) and the hypotheses above. To test the SEM, survey data were collected in a highly developed food market (Austria). To analyze whether, for example, the WTP for aquaponic products is significantly and directly driven by the purchase intention and indirectly driven by the assessment of aquaponics or environmental awareness and green consumption, SEM is a commonly used approach. Successful implementation on the Austrian market requires, on the one hand, the provision of information for consumers. On the other hand, environmentally conscious consumers can be addressed as a target 
group. If these two aspects are taken into account, the influence of environmental awareness and green consumption and the assessment of aquaponics can lead to a higher purchase intention and, consequently, to a higher willingness to pay, according to the SEM.

This paper is organized as follows: in the second chapter, we summarize prior research and develop the research framework. In the third chapter, we outline the research design with the sample procedure, measures, and reliability and validity tests. The results of the structural model are presented in the fourth chapter, followed by a discussion in the fifth chapter. Finally, we draw conclusions based on our analytical results in the sixth chapter.

\section{Literature Review}

There are several research projects that shed light on the scientific and technical aspects of aquaponics [11]. Yep and Zheng [9] provide a comprehensive literature review of the technical aspects of aquaponics. However, only a few studies deal with commercial questions [6,25], such as Blidariu and Grozea [26], who focus on the economic aspects of aquaponics, or Bosma et al. [27], who investigate the financial feasibility of aquaponics by means of a cost-benefit analysis. Social acceptance and the attitudes of potential consumers are particularly decisive for the success of aquaponic products in the market $[28,29]$. Furthermore, several studies show that consumer perceptions of aquaponics differ according to the definition and the values associated with it $[21,28,30]$. Regional and antibioticand pesticide-free production are strong purchasing arguments that reflect the consumer's positive engagement $[21,30]$. However, high technology use and intensive production, as well as little knowledge about the products, leads to negative consumer opinions, according to current research [21,28]. In addition, the formerly mentioned impossibility of organic certification is an important barrier [21]. In addition to differentiation-according to the values attributed to aquaponics-there are also differences, depending on the country in which the study is conducted $[10,21,28,30,31]$. A study by Tamin et al. [31] investigated the reaction of Malaysian customers to aquaponic products. The outcome was a positive buying interest. Zugravu et al. [30] examined consumer perception and the image of aquaponics in Romania. The framework concept of these studies assumes that the general perception of aquaponic products includes product opinion, price, and value. These variables are, in turn, influenced by demographic data, financial situations, and the influence of third parties on purchasing experience and information [30]. Furthermore, the study of Zugravu et al. [30] showed that domestic aquaponic products received more attention than foreign products and were preferably bought. Specht et al. [28] identified the general preferences of the inhabitants of Berlin (Germany) for the productive use of urban space, the acceptance of different forms of urban agriculture, and the perceptions of urban agricultural products. Specht et al. [28] showed that the greatest acceptance was achieved for an agricultural production system that combined commercial goals with environmental and social goals. This meant that systems with a predominantly profit-oriented and technologically intensive alignment were increasingly rejected [28], whereas aquaponic systems received poorer evaluations: only $28 \%$ of study respondents approved aquaponics as a production system for fish and vegetables, and only $27 \%$ would buy these products [28]. Miličić et al. [21] conducted a Europe-wide survey and found that consumer acceptance was generally positive and that consumers were also willing to pay more for products free of antibiotics, pesticides, and herbicides, and for products that came from local suppliers. Greenfeld et al. [10] showed that between $17 \%$ and $30 \%$ of Australian and Israeli consumers were willing to consume aquaponic products. However, according to their findings, the price premium would be rather low.

\subsection{Familiarity with and Knowledge about Aquaponics (FA)}

Aquaponic products face a major communication challenge because their food production system is unknown, they have a high degree of innovation and require generally high technological effort [24,32]. The low level of awareness among consumers is shown in the study by Miličić et al. [21], where $50 \%$ of the respondents stated that they had never heard of aquaponics, while only $30 \%$ had never 
heard of hydroponics. This data is comparable to Greenfeld et al. [10], where $56 \%$ of an Australian sample claimed to be familiar with aquaponics, but only $17 \%$ of the Israeli sample were familiar with it. The finding leads to the assumption that knowledge about aquaponics might also be influenced by culture and previous consumption habits of fish. In principle, information and knowledge play important roles in the purchasing decisions of consumers. Behavioral literature generally speaks of a positive relationship between knowledge and behavior [33-35]. Moreover, Hoffmann and Akbar [36] predicated that it is only possible for consumers to weigh alternatives when they have sufficient knowledge. The influence of knowledge was also confirmed by Zugravu et al. [30], who found that existing knowledge is essentially linked to the intention to buy aquaponic products. Furthermore, Tamin et al. [31] claimed that a lack of information has a negative influence on the attitude towards aquaponics and reduces the willingness to buy.

\subsection{Environmental Awareness and Green Consumption (EAGC)}

"Environmental awareness" can be seen as a multidimensional attitude construct, with proximity to purchasing behavior [37]. According to Monhemius [37], the term can be understood as the knowledge and insight of the consumer about the ecological consequences of individual buying decisions and consumption behavior, whereas "green consumption" is a given when predominantly environmentally friendly and sustainable products are purchased and products that burden the environment and society are avoided $[35,37,38]$. Aquaponics is regarded as a sustainable and environmentally friendly system $[7,8,12]$ and it is also perceived as such among consumers [21,28,31]. However, aquaponic systems require a high technology input and are energy-intensive, which, in turn, could be a deterrent for environmentally conscious consumers [28]. Despite that, Tamin et al. [31] classified aquaponic products as green products. According to Peattie [39], a product can be considered as a green product if it shows significant improvements (in production, consumption, and disposal) in favor of the environment compared to conventional products. Tamin et al. [31] also showed that consumers are aware of the importance of environmentally friendly products and believe that by purchasing environmentally friendly products, such as aquaponics, they are helping to protect the environment.

\subsection{Attitude and Purchase Intention (PI)}

Attitude is the general permanent assessment of people, objects, or topics [40]. The three-component theory plays an important role in attitude research. It states that attitudes are composed of affective, cognitive, and action-related components, and it focuses on the hypothesis that there is a connection between current attitudes and future behavior [41]. An attitude directly influences the behavior intention and, indirectly, the behavior. However, no direct conclusion should be drawn from a found attitude-purchasing intention relationship to an attitude-behavior relationship [40] because other factors, such as situational conditions, personality factors, or involvement, are also decisive for the actual buying behavior [42]. The connection between attitude and purchase intention was confirmed by the literature in several studies [31,43-45]. The study by Barber et al. [43] tested the influence of environmental knowledge and the attitude of wine consumers on their purchase intentions and showed a positive correlation between them. Furthermore, Hartmann and Apaolaza-Ibáñez [44] determined a connection between consumer attitudes and buying intentions with regard to green energy brands. A positive and significant relationship was also found by Kozup et al. [45] regarding attitude and the intention to buy organic products. Finally, Tamin et al. [31] applied the theory of planned behavior to determine consumer behavior regarding aquaponic products and confirmed a connection between the attitude dimension and the intention to buy for aquaponic products. The theory of Ajzen's [46] planned behavior is the best-known theory for explaining attitude-behavior coherence [36].

\subsection{Willingness to Pay (WTP)}

In business, the maximum amount that an individual is willing to pay for a particular product is usually taken as a measure of the value of a good to the individual [47]. Here, the benefit of the product 
for the buyer plays a major role. The product will only be bought if the benefit for the consumer is greater than the price to be paid. The study of Miličić et al. [21] surveyed the WTP for aquaponic products by means of comparative questions. It discovered that local, pesticide-, herbicide-, and antibiotic-free products are preferred. In particular, $75 \%$ of the respondents expressed that they would pay the same price for local products that were conventionally produced as for aquaponic products. More generally speaking, WTP seems to be influenced by a number of factors. Bower et al. [48] showed that WTP is significantly influenced, among other factors, by the intention of consumers to buy a certain product: if consumers are willing to buy a product, they are also willing to pay a price premium. Zhang et al. [49] examined factors influencing the consumer's purchase intention and willingness to pay a price premium for safe vegetables. Besides individual and family characteristics, factors such as attitude, price, safety perceptions, and purchase consciousness were tested. The findings showed that $67.6 \%$ of consumers were willing to buy safe vegetables and $65.8 \%$ were willing to pay a higher price. For aquaponic vegetables, this means that it may well be interesting to see whether consumers perceive them as safe vegetables and whether this leads to a price premium [49]. Another example of a conceptual model where the influence of search attributes (product information) on PI and of PI on WTP is assumed can be taken from $\mathrm{Xu}$ et al. [50].

On the basis of this model (Figure 1), the influencing factors on WTP are to be determined. This model is based on the findings from the literature presented above. We expect that knowledge of aquaponics influences WTP. However, it must be assumed that the level of awareness of aquaponics among Austrian consumers is very low and, for this reason, no or only little knowledge is available. Therefore, instead of the variable "knowledge," the variable "familiarity" was inserted into the model. Thus, we propose that: familiarity with aquaponics (FA) has a significant and positive impact on the willingness to pay (WTP) (H1) and on the purchase intention (PI) (H2). Furthermore, high environmental awareness leads to a better evaluation of green products, according to the literature [51-55]. Jaiswal and Kant [55] confirmed a positive and significant impact of environmental concern on the attitude towards green products and Chen and Peng [51] stated that a sense of responsibility for the environment encourages consumers to buy green products. Moreover, one of the crucial factors for a positive attitude towards organic products, which are also classified as green products, is environmental concern [52-54]. This leads to the assumption that consumers with environmentally friendly purchasing behavior assess aquaponic products more positively and that this also has an impact on purchase intention and WTP. In light of the above, we propose that: environmental awareness and green consumption (EAGC) have a positive and significant impact on the assessment of aquaponics (AA) (H3), on the intention to buy (PI) (H4), and on the willingness to pay (WTP) (H5). Based on the literature (Section 2.3), a positive correlation between attitude and purchase intention (PI) was assumed. Since we expected a low familiarity with aquaponics (FA), a comprehensive measurement of the attitude (and the dimensions of the attitude) was less appropriate. For this reason, the construct "attitude" was simplified to the construct "assessment of aquaponics" (AA). In the AA construct, new product ideas will be the focus, and, therefore, AA will be evaluated after a short product/system description. This leads to H6: the assessment of aquaponics (AA) has a positive and significant impact on purchase intention (PI). Finally, it is assumed that both AA and PI influence the WTP (H7, H8). 


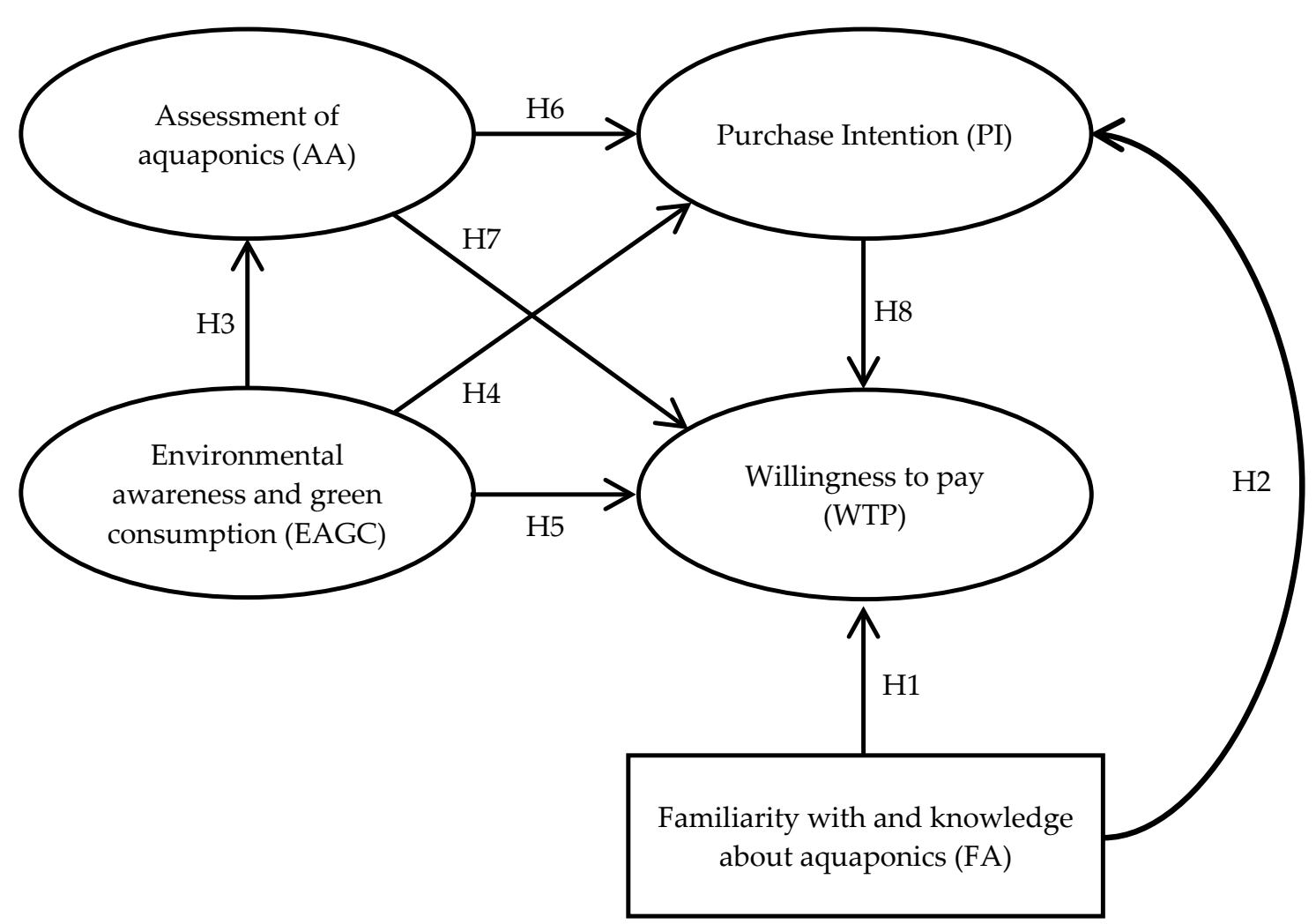

Figure 1. Proposed research framework.

\section{Materials and Methods}

The data were analyzed using IBM SPSS Statistics 24 in combination with IBM SPSS AMOS 24. Two pretests were conducted. The first pretest was conducted with 40 participants. Using the data from the first pretest, a comprehensive quality check of the measurement model was carried out. This quality test revealed weaknesses in the constructs of WTP, AA, and EAGC. For this reason, new measures were chosen for these constructs. Due to a large number of changes made in the first questionnaire, a further pretest with $\mathrm{N}=38$ was carried out. Based on the second pretest results, negligible changes were implemented, the final questionnaire was designed, and the general analysis was carried out.

\subsection{Sample Size and Characteristics}

The survey was conducted by means of a face-to-face interview with closed questions in a questionnaire. The implementation of the survey by personal interviews was chosen due to the fact that participants take more time to answer the questions, the instrument is more accurate, and the non-response rate is lower $[56,57]$. The interviews were conducted in Austria, in the large city of Vienna, in the smaller cities of Amstetten, Wels, and Salzburg, and in rural village areas around Berndorf bei Salzburg and Neuhofen an der Ybbs. The survey took place in February, 2019. Although we tried to reach specific quotas in terms of gender, age, income, etc., the sample was still a non-probabilistic convenience sample. A sample size of $n=349$ was achieved. By eliminating outliers, removing the latent variable "product experience" from the model (only five respondents stated that they had product experience), and excluding incomplete questionnaires, the final dataset amounted to 315 cases. According to Hair et al. [58] and Kline [59], the sample size (N) should be greater than 10 to 15 times the number of the parameters/items $(t)$ in the model. The number of parameters/items was $t=19$, so a sample size of $n=285$ was required. The sample size of $n=315$ was, therefore, appropriate.

Table 1 shows the demographic information of the sample respondents $(n=315)$ in comparison with the overall Austrian population. As we can see from Table 1, the sample quota differs somewhat 
from the overall Austrian population (slightly more females, fewer respondents below 20 and above 60 , more rural places of residence, and a higher educated sample with, on average, a higher income). The transferability of the results is, therefore, limited.

Table 1. The demographic profile of respondents.

\begin{tabular}{|c|c|c|c|c|}
\hline & Description & Frequencies & Valid \% & Austria \% ${ }^{a}$ \\
\hline \multicolumn{5}{|l|}{ Gender } \\
\hline & Male & 150 & 47.6 & 50.8 \\
\hline & Female & 165 & 52.4 & 49.2 \\
\hline \multicolumn{5}{|l|}{ Age } \\
\hline & $\leq 20$ & 21 & 7.3 & 20.8 \\
\hline & $21-30$ & 79 & 27.6 & 13.2 \\
\hline & $31-45$ & 72 & 25.2 & 20.2 \\
\hline & $46-60$ & 84 & 29.4 & 22.6 \\
\hline & $61+$ & 30 & 10.5 & 23.1 \\
\hline & Missing & 29 & & \\
\hline \multicolumn{5}{|l|}{ Place of residence } \\
\hline & Rural & 208 & 66.2 & 47.2 \\
\hline & Urban & 106 & 33.8 & 52.8 \\
\hline & Missing & 1 & 33.8 & 52.8 \\
\hline \multicolumn{5}{|l|}{ Education } \\
\hline & Compulsory school & 21 & 6.7 & 18.0 \\
\hline & Apprenticeship/middle school & 124 & 39.5 & 48.8 \\
\hline & High school diploma & 93 & 29.6 & 15.6 \\
\hline & University & 76 & & \\
\hline & Missing & 1 & 24.2 & 17.5 \\
\hline Income per month & Mean income per month & & estimated 2183 to 2461 & 1887 \\
\hline
\end{tabular}

\subsection{Measures}

Measurement scales were used, whose validity had already been already confirmed in other studies. The scales used to determine EAGC (environmental awareness and green consumption) was a six-item and seven-point Likert-type scale, based on Miličić et al. [21]. The questions were [21]: I actively look for ways to buy from local farmers (e.g., buy at open air markets or directly from farmers); when I buy vegetables, I look for pesticide- and herbicide-free produce; I am careful when buying fish and would rather pay more for organically produced fish; when buying in a supermarket, I take the locally produced food, even if it is more expensive; when I buy food, I have to consider price as the most important factor for the decision; if the price of organic produce is twice the price of non-organic produce, I decide on non-organic produce. In the Appendix A in Table A1, the final questions regarding EAGC can be found (including frequencies, mean, and standard deviation). The scales used to determine AA (assessment of aquaponics) was a six-item and seven-point Likert-type scale, based on Miličić et al. [21] and Ratneshwar and Chaiken [60], respectively. Ratneshwar and Chaiken [60] developed the indicator variables to determine attitudes towards new products. The interviewees were first presented with a description of the new product idea, and then with questions about attitude. Two additional indicator variables were added to AA—one indicator about the sustainability of aquaponics and one about the protection of the oceans: aquaponic produce supports the conservation of the sea; aquaponics delivers answers for sustainable food production. The final, detailed questions on AA are also provided in Table A1 in the Appendix A. The indicator variables of PI originated from the work of Miličić et al. [21]. We asked five questions on a seven-point Likert-type scale. The questions were [21]: next time I buy vegetables, I will look for aquaponically grown vegetables; when deciding between conventionally farmed fish and aquaponically farmed fish, I would choose aquaponics fish; I would choose aquaponics fish even if they cost more; aquaponics is the answer to a more sustainable 
food production; most of the scare about pesticides and herbicides is exaggerated; I like the idea, but I doubt I would actually eat the fish or vegetables grown in this way. Small adjustments have been made to these questions and the final questions can be found in Table A1 in the Appendix A. Moreover, a four-item, seven-point Likert-type WTP scale was adopted from Voon et al. [61]. Voon et al. [61] determined consumers' WTP for organic products, and we modified it into the variable "willingness to pay for aquaponic products." The questions were [61]: I'm willing to buy organic food even though choices are limited; I'm willing to buy organic food because the benefits outweigh the cost; buying organic food is the right thing to do, even if they cost more; I don't mind spending more time sourcing for organic food; I would still buy organic food even though conventional alternatives are on sale (Table A1 in the Appendix A). The FA variable was surveyed with a bi-nominal (yes-no) question (Table A2 in the Appendix A).

\subsection{Testing the Hypotheses through SEM}

SEM is suitable for determining the extent to which the theoretical framework is supported by empirical data. SEM was chosen for the analysis of the current study based on three reasons: (1) in structural equation analyses, it is possible to include variables that cannot be measured directly (latent variables). In marketing research especially, SEM is an important tool [62] that is often used for questions concerning the influence of important variables of consumer behavior [63]. In our study were the following latent variables: EAGC, AA, PI, and WTP. (2) Structural equation models are suitable for analyzing causal and complex relationships between individual constructs when compared with basic statistical methods. SEM allows multiple dependent and independent variables in the model. This makes SEM a preferred method for the quantitative testing of theoretical models [64]. (3) The focus of this study was not the amount of WTP expressed in a numerical, monetary value, but the factors influencing it. If the focus was on the WTP itself, auctions or experimental settings would be the chosen methods.

\subsection{Reliability and Validity Analysis}

For testing reliability and validity, an Exploratory Factor Analysis (EFA) was used first to check one-dimensionality and communalities. Secondly, a Confirmatory Factor Analysis (CFA) was conducted to confirm each indicator of the construct. In the end, an SEM was carried out to verify the conceptual framework and to test the hypotheses using AMOS with a maximum likelihood estimation.

Testing for one-dimensionality using EFA: the EFA was used to remove any indicators from the measurement that were not sufficiently correlated with a factor and to check the one-dimensionality of an indicator set [65]. The Kaiser-Meyer-Olkin (KMO) criterion, the Bartlett test, and the factor values were consulted for verification. The KMO values of the constructs ranged between 0.737 ("middling") and 0.891 ("meritorious") and were above the cut-off value of 0.6 [66]. The Bartlett test was rejected for all variables in this study and the sample matrix showed one-dimensionality for all constructs (Table 2). 
Table 2. Exploratory Factor Analysis.

\begin{tabular}{|c|c|c|c|c|c|c|}
\hline & Item & KMO Value & $\begin{array}{l}\text { Composite } \\
\text { Reliability }\end{array}$ & Cronbach's $\alpha$ & AVE & SMC \\
\hline \multicolumn{7}{|l|}{ EAGC } \\
\hline & Local & \multirow{4}{*}{$\begin{array}{c}0.737 \\
\text { (middling) }\end{array}$} & \multirow{4}{*}{0.744} & \multirow{4}{*}{0.738} & \multirow{4}{*}{0.421} & 0.434 \\
\hline & Purchase of fish & & & & & 0.442 \\
\hline & Regional & & & & & 0.431 \\
\hline & Pesticide-free & & & & & 0.375 \\
\hline \multicolumn{7}{|l|}{ AA } \\
\hline & Appropriate Price & \multirow{6}{*}{$\begin{array}{c}0.891 \\
\text { (meritorious) }\end{array}$} & \multirow{6}{*}{0.931} & \multirow{6}{*}{0.929} & \multirow{6}{*}{0.695} & 0.610 \\
\hline & Reasonable & & & & & 0.772 \\
\hline & Positive & & & & & 0.827 \\
\hline & Very good & & & & & 0.793 \\
\hline & Protection of the ocean & & & & & 0.536 \\
\hline & Sustainability & & & & & 0.632 \\
\hline \multicolumn{7}{|l|}{ PI } \\
\hline & Aquaponic vegetables & \multirow{5}{*}{$\begin{array}{c}0.847 \\
\text { (meritorious) }\end{array}$} & \multirow{5}{*}{0.927} & \multirow{5}{*}{0.927} & \multirow{5}{*}{0.717} & 0.631 \\
\hline & Good Idea & & & & & 0.759 \\
\hline & Fish higher price & & & & & 0.745 \\
\hline & Aqua fish & & & & & 0.742 \\
\hline & Vegetables higher price & & & & & 0.706 \\
\hline \multicolumn{7}{|l|}{ WTP } \\
\hline & Variety & \multirow{4}{*}{$\begin{array}{c}0.814 \\
\text { (meritorious) }\end{array}$} & \multirow{4}{*}{0.912} & \multirow{4}{*}{0.902} & \multirow{4}{*}{0.724} & 0.703 \\
\hline & Good one & & & & & 0.866 \\
\hline & Advantage & & & & & 0.880 \\
\hline & Procurement & & & & & 0.447 \\
\hline
\end{tabular}

$\overline{\mathrm{KMO}}$ = Kaiser-Meyer-Olkin criterion; AVE = Average Variance Extracted; SMC = Squared Multiple Correlations.

Construct and indicator reliability: for testing indicator and construct reliability, Cronbach's $\alpha$, inter alia, was considered. The minimum cut-off level for Cronbach's $\alpha$ was 0.7 [67]. The values of Cronbach's $\alpha$ for the constructs in this study (EAGC, AA, PI, and WTP) varied from 0.738 to 0.927 and were above the required level.

Indicator reliability-Squared Multiple Correlations (SMC): Indicator reliability indicates whether the loadings are important. The root calculated from the SMC (charge squares) results in the factor charges. Composite reliability and AVE are calculated on the basis of factor charges [68]. Bagozzi and Baumgartner [69] suggested the cut-off value of 0.4 for SCM. Only the indicator variable "pesticide-free" (0.375) was slightly below this value and was considered less important.

Composite reliability: The composite reliability corresponds to the indicator reliability at the construction level. According to Bagozzi and Yi [70], the values should be greater than 0.6. All constructs reached a value above 0.6. AA reached a value of 0.931 , PI of 0.927, EAGC of 0.744 , and WTP of 0.912 .

Average Variance Extracted (AVE): The AVE indicates, on average, what percentage of the dispersion of the latent construct over the indicators is explained [68]. Fornell and Larcker [71] suggested a minimum value of 0.5 . The values ranged from 0.421 to 0.724 . The threshold value of 0.5 could not be reached for the single EAGC variable. Due to the fact that the measure for EAGC was already confirmed in a study by Miličić et al. [21], the construct and the indicators were retained.

Validity of the model with CFA: A construct validity is given when a convergent, discriminant, and nomological validity is confirmed [72]. The measurement must not be falsified by other constructs or systematic errors [68].

Nomological validity: In nomological validity, the focus is on the relationships between the different constructs, as well as the relationships of the constructs to their measurement indicators [72]. The verification of nomological validity was carried out using the parameter estimates of the CFA. The hypotheses can be confirmed by the results in Table 3 . All latent variables were positively correlated. 
Due to the overall positive and predominantly significant factor loads, a nomological validity of the construct could be assumed.

Table 3. Tested hypothesis, results from the Confirmatory Factor Analysis (CFA).

\begin{tabular}{ccccccc}
\hline Construct & $\mathbf{d}$ & Construct & Estimate & S.E. & C.R. & $p$ \\
\hline EAGC & $\leftrightarrow$ & AA & 0.352 & 0.059 & 5.933 & $* * *$ \\
EAGC & $\leftrightarrow$ & PI & 0.548 & 0.051 & 10.747 & $* * *$ \\
EAGC & $\leftrightarrow$ & WTP & 0.603 & 0.047 & 12.933 & $* * *$ \\
AA & $\leftrightarrow$ & PI & 0.852 & 0.020 & 43.383 & $* * *$ \\
AA & $\leftrightarrow$ & WTP & 0.825 & 0.021 & 38.761 & $* * *$ \\
PI & $\leftrightarrow$ & WTP & 0.952 & 0.010 & 96.407 & $* * *$ \\
\hline
\end{tabular}

$\mathrm{d}=\overline{\text { direction; S.E. }=\text { Standard Error; C.R. }=\text { C.R.-value; } p=p \text {-value (statistical significance) }{ }^{* * *} p<0.001}$.

Convergence validity: Evidence for convergence validity can be derived from the average variance extracted [71]. With one exception, all AVE values were above 0.5 (Table 2). Only the EAGC construct had an AVE value of 0.421 , which was too low.

Discriminant validity: The measurements of the constructs must differ significantly before discriminant validity is given. If one-dimensionality is achieved in the EFA, this is a good indicator of the existence of discriminant validity [68]. All constructs of this study exhibited one-dimensionality in themselves.

Furthermore, discriminant validity should be carried out on the basis of the CFA. The CFA that was already carried out to assess the reliability of the measurement models had the function of a so-called unrestricted model $(\mathrm{Mu})$. This meant that the factor correlations in this model were freely estimated. This analysis revealed a chi-square value of $\chi 2-\mathrm{Mu}=525.1$. Afterwards, it was necessary to create restricted models (Mr). The covariance was fixed to 1 between two latent variables.

$\chi 2-\mathrm{M}_{\mathrm{r}}(\mathrm{EAGC}$ and PI $)=689.7 \rightarrow \chi 2$-difference $=164.6$

$\chi 2-\mathrm{M}_{\mathrm{r}}(\mathrm{AA}$ and $\mathrm{EAGC})=751.9 \rightarrow \chi 2$-difference $=226.8$

$\chi 2-\mathrm{M}_{\mathrm{r}}(\mathrm{AA}$ and $\mathrm{WTP})=836.1 \rightarrow \chi 2$-difference $=311$

$\chi 2-\mathrm{M}_{\mathrm{r}}(\mathrm{AA}$ and $\mathrm{PI})=761.2 \rightarrow \chi 2$-difference $=236.1$

$\chi 2-\mathrm{M}_{\mathrm{r}}(\mathrm{WTP}$ and EAGC $)=672.4 \rightarrow \chi 2$-difference $=147.3$

$\chi 2-\mathrm{M}_{\mathrm{r}}(\mathrm{PI}$ and $\mathrm{WTP})=568.3 \rightarrow \chi 2$-difference $=43.2$

The $\chi 2$-difference values should be above the critical value of 3.84. This is the case for all restricted models. Finally, the Fornell/Larcker criterion can be used. The AVE value should be greater than the squared correlation [71]. The AVE values were all greater than the squared correlations between the factors, with the exception of the link between WTP and PI. The AVE values of the constructs were 0.724 and 0.717 , but the squared correlation was 0.906 . Nonetheless, due to the given one-dimensionality of the constructs and the $x 2$-difference values, discriminant validity was assumed (but subject to reservations, which will be considered in the limitations).

\section{Results of the Structural Model}

After the evaluation of the measurement model, the structural model was examined using the goodness of fit statistics $\left(\chi^{2}=632.079, \mathrm{df}=218, \chi 2 / \mathrm{df}=2.899, \mathrm{RMSEA}=0.078, \mathrm{IFI}=0.924, \mathrm{TLI}=0.912\right.$, and CFI $=0.924)$. The model fit can be classified as acceptable. The $\chi 2 / \mathrm{df}$, root mean square error of approximation (RMSEA), comparative fit index (CFI), incremental fit index IFI, and Tucker-Lewis index (TLI) were within the required range and, thus, indicated an acceptable model quality: $\chi 2 / \mathrm{df} \leq 3$, according to Homburg and Giering [65]; RMSEA $\leq 0.08$, according to Browne and Cudeck [73]; CFI $\geq 0.9$, according to Bentler [74]; IFI $\geq 0.9$, according to Bollen [75]; and TLI $\geq 0.9$, according to Homburg and Baumgartner [76]. The hypothesis system was tested by means of a path diagram using 
the standardized regression weight and $p$-values (Table 3). The purpose was to evaluate the effect of independent variables on dependent variables.

Moreover, $\mathrm{R}^{2}$ gives information about the variance share of an endogenous latent variable, which is explained by the other latent variables [77,78]. In this model, there were three dependent variables: namely, AA, PI, and WTP. EAGC explained 13\% of the variance of AA. EAGC, FA and AA explained $83 \%$ of the PI and, furthermore, EAGC, FA, AA, and PI collectively explained $91.9 \%$ of the variance of WTP (Table 4).

Table 4. Explained variance of dependent variables $\left(R^{2}\right)$.

\begin{tabular}{cc}
\hline Construct & Estimate \\
\hline AA & 0.130 \\
PI & 0.830 \\
WTP & 0.919 \\
\hline
\end{tabular}

The present study was based on the hypothetical model that examined the direct or indirect effects of EAGC, AA, and FA on PI and WTP. The result of the path analysis is shown in Table 5. Most of the hypotheses ( $\mathrm{H} 2, \mathrm{H} 3, \mathrm{H} 4, \mathrm{H} 5, \mathrm{H} 6$, and $\mathrm{H} 8$ ) were accepted at $p \leq 0.05$, except for $\mathrm{H} 7$ (i.e., AA $\rightarrow$ WTP) and H1 (i.e., FA $\rightarrow$ WTP) in the model of the present study. More specifically, the following conclusions can be drawn based on SEM and the tested hypotheses:

- It was assumed that if consumers had already heard of aquaponics, this would have a positive effect on WTP and PI. Based on the results (H1 $\beta=-0.022 ; p=0.390 ; \mathrm{H} 2 \beta=-0.068 ; p=0.029$ ), we found no relationship between FA and WTP and rejected H1. However, AA seemed to influence PI, supporting $\mathrm{H} 2$ on a 0.05 significance level (the negative sign of $\beta=-0.068$ was due to the measurement scale of the basic items with $1=$ totally agree to $7=$ totally disagree). If a respondent was familiar with aquaponics, PI was slightly higher, but this effect was very low (almost negligible), particularly when compared to other variables in the model.

- The results indicated that EAGC had a positive and direct effect on AA, the standardized regression weight amounted to $\beta=0.361$, and the significance to $\left.p<0.001{ }^{(* *}\right)$, supporting H3. Consequently, as expected in H4, AA had a positive and strong influence on PI $(\beta=0.738 ; p<0.001)$. We did find a weak relationship between EAGC and WTP $(\beta=0.136 ; p=0.003)$, supporting H5.

- As expected in H6, we further detected a strong and significant influence of AA on PI ( $\beta=0.738$; $p<0.001)$. However, we did not find a significant relationship between AA and WTP $(\beta=0.076$; $p=0.316)$, and rejected H7. Finally, we found a strong and positive impact of PI on WTP ( $\beta=0.812$; $p<0.001)$, supporting H8.

Table 5. Tested hypotheses.

\begin{tabular}{cccccccc}
\hline Hypothesis & Construct & $\mathbf{d}$ & Construct & Estimate $^{*}(\beta)$ & Estimate & $p$ & Result \\
\hline H1 & WTP & $\leftarrow$ & FA & -0.022 & -0.083 & 0.390 & Rejected \\
H2 & PI & $\leftarrow$ & FA & -0.068 & -0.235 & 0.029 & Supported \\
H3 & AA & $\leftarrow$ & EAGC & 0.361 & 0.372 & $* * *$ & Supported \\
H4 & PI & $\leftarrow$ & EAGC & 0.327 & 0.338 & $* * *$ & Supported \\
H5 & WTP & $\leftarrow$ & EAGC & 0.136 & 0.157 & 0.003 & Supported \\
H6 & PI & $\leftarrow$ & AA & 0.738 & 0.739 & $* * *$ & Supported \\
H7 & WTP & $\leftarrow$ & AA & 0.069 & 0.076 & 0.315 & Rejected \\
H8 & WTP & $\leftarrow$ & PI & 0.812 & 0.901 & $* * *$ & Supported \\
\hline
\end{tabular}

Standardized Regression weights (Estimate*,$\beta$ ), non-standardized Regression weights (Estimate) and $p$-values $(* * *<0.001)$. 


\section{Discussion}

This study examined whether environmental awareness and green consumption, the assessment of aquaponics, purchase intention, and familiarity with aquaponics influences the willingness to pay for aquaponic products. We found a strong effect of EAGC on AA and a medium effect on the PI regarding aquaponic products. This result indicates that consumers consider aquaponics to be good for the environment. Environmentally conscious consumers rate aquaponics more positively and have a higher PI. These findings are in accordance with the literature, confirming that aquaponics may be considered a sustainable food production system and aquaponic products may be considered green products $[6-8,21,31]$. Furthermore, the findings of this study support previous studies, showing that environmental awareness is one of the strongest antecedents of attitudes towards green products and green purchase willingness [51-55,79-81].

Furthermore, the AA construct displayed a direct and highly significant influence on PI. Honkanen et al. [82] stated that the attitude of a person to a subject or to the evaluation of a product is one of the most important explanations for a consumer's decision to use a particular product (including food) or service. Much of the literature has focused on the attitude-purchasing intention relationship and confirmed this connection in several studies [31,43,44]. Both the three-component theory and the theory of planned behavior are also based on this attitude-purchasing intention context [42,46]. Moreover, there are several studies confirming that PI is driven by the measure of attitude in the green consumer behavior literature [55,83-85]. However, both the literature and the empirical results of this study point to a direct, strong, and highly significant influence of AA on PI. However, a direct effect of AA on WTP was not proven.

Our research also found support for the relationship between PI and WTP. It appears, therefore, that consumers who have a high intention of purchasing aquaponic products are also willing to pay more for them. Considering that PI and WTP as constructs are by definition already very similar, the direction of the relationship between PI and WTP is controversially discussed in the literature. Bower et al. [48], as well as Xu et al. [50], indicate the direction of action from the PI to the WTP. Voon et al. [61] treated WTP as an antecedent of PI but did so without further explanation. Nevertheless, WTP is the latent variable, about which a final statement is to be made. The significant regression weight of 0.812 between PI and WTP and the $\mathrm{R}^{2}$ of 0.919 underpinned the direction of action in the model.

Finally, we did not find support for the influence of FA on WTP (and only a very low influence of FA on PI). According to our data, there was no significant evidence that consumers who were familiar with aquaponics reacted differently concerning WTP. The effect size of FA on PI was, although significant, almost negligible. This might be due to the low number of respondents in our study who stated that they had already heard about aquaponics (12.4\%). Therefore, this influencing factor seemed questionable in the actual model. However, we assumed that FA might influence WTP and PI as soon as aquaponic products are well established on the food market and more people become aware of them.

To sum up, and to answer the central research question, the most important direct influential factor on WTP is PI. EAGC and AA are significant indirect factors that influence WTP (the direct effect of EAGC on WTP is rather weak). Altogether, the three latent variables and the other effects account for $91.9 \%$ of the variance of WTP (Figure 2). 


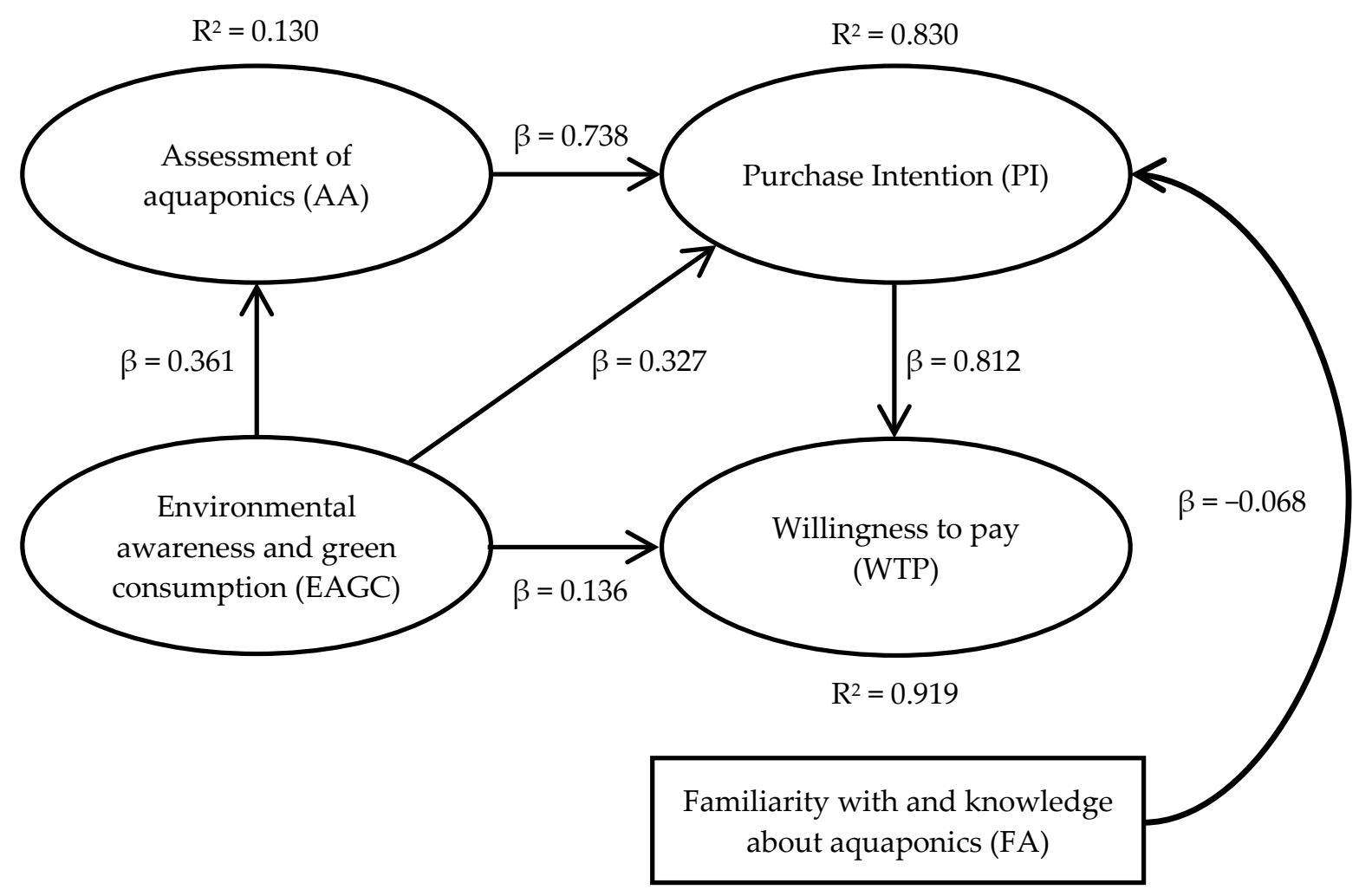

Figure 2. Tested structural model.

\section{Conclusions}

Confirming our results, aquaponic products that are placed on the market as a sustainable food alternative are likely to be highly accepted by environmentally aware consumers. However, aquaponics as a food production system is not self-explanatory (and up to now, knowledge and familiarity seem to be limited). In particular, the low familiarity with aquaponic systems among Austrian consumers can pose a major problem in marketing. For the Austrian aquaponics industry, we suggest taking on measures that increase the familiarity of aquaponics among Austrian consumers. This can be achieved, for example, via an information campaign involving the producers of aquaponics products. Due to the high complexity of aquaponic systems, we propose the preparation of the information in a consumer-friendly manner. It is thought that familiarity also plays an important role in an international context. Therefore, other countries should be aware of their consumers' familiarity with aquaponic products. As our results show, the assessment of aquaponics influences the purchase intention and, indirectly, the willingness to pay. For this reason, the attitude towards aquaponics plays a major role. In our SEM, the environmental awareness and green consumption of consumers was stated as a strong factor that influences the assessment of aquaponics. The consumers who were most willing to buy aquaponic products and also had a higher WTP were those with higher environmental awareness and green purchasing behavior. This result offers the Austrian (and, presumably, the international) aquaponics industry the opportunity to focus their marketing on environmentally aware consumers. To reach this target group, the environmental advantages of aquaponics should be highlighted in the communication policy. To highlight the sustainability of aquaponics, the absence of pesticides in vegetables, the production at the place of consumption (short transport distances through the possible urban production), and the efficient utilization of nutrients in aquaponic systems could be accentuated.

Considering all these advantages and arguments in the communication of aquaponics, a high acceptance among consumers is likely to be reached in highly developed food markets. In conclusion, a marketing strategy based on information transfer and environmental protection issues leads to a 
positive assessment of aquaponics, and, as the structural model shows, this leads to higher monetary remuneration for producers of aquaponic fish and vegetables, too, as the purchase intention and willingness to pay also increases. Considering the current environmental and climate developments and our results, we think that there is potential for aquaponic products on the future market.

Limitations and future research: a few limitations are noted, suggesting some avenues for future research. (1) Even though we achieved a broad sample structure, the study does not reflect the general population in Austria due to the fact that the selection procedure presented nonprobability sampling. (2) The results only reflect the opinions of consumers in one specific, highly developed food market. Future studies might investigate different markets, countries, and cultures. (3) A further limitation is evident through the reduced complexity of the structural model. Variables such as knowledge, quality, safety perception, subjective norm, and perceived behavioral control were not explicitly considered in the model. In further research, the model could be extended by including these variables, especially to consider the theory of planned behavior to its full extent [46]. However, due to the expected low degree of the consumer's familiarity with aquaponic products, the reduced complexity of the model was appropriate. (4) The latent variable EAGC is only moderately represented by its set of indicators. This set of indicators could be adjusted in order to achieve better quality. (5) The constructs WTP and PI do not differ sufficiently according to the Fornell/Larcker criterion. In future research, attention should be paid to a sufficient differentiation of these constructs. (6) The willingness to pay in this study was not measured by a numerical value but by statements. In a further investigation, the WTP could also be measured numerically to determine the actual WTP. (7) Due to the low level of familiarity with aquaponics among consumers $(12.4 \%)$, a relatively high level of hypothetical bias may occur. The more the consumer is familiar with the product, the lower the hypothetical bias is [86,87]. (8) Considering the questions of this study in a purely descriptive context, it is evident that there is a tendency towards the positive direction; this could be an indication of "yes saying." Nevertheless, the whole spectrum of answer possibilities was mostly used.

Author Contributions: Conceptualization, T.E. and O.M.; methodology, T.E. and O.M.; software, T.E.; validation, T.E. and O.M.; formal analysis, T.E.; investigation, T.E. and O.M.; resources, T.E. and O.M.; data curation, T.E.; writing—original draft preparation, T.E.; writing—review and editing, O.M.; visualization, T.E. and O.M.; supervision, O.M.; project administration, T.E. and O.M.; funding acquisition, T.E. and O.M. All authors have read and agree to the published version of the manuscript.

Funding: This research received no external funding.

Conflicts of Interest: The authors declare no conflict of interest. 


\section{Appendix A}

Table A1. Constructs: Frequencies, mean, and standard deviation.

\begin{tabular}{|c|c|c|c|c|c|c|c|c|c|c|c|}
\hline \multirow{2}{*}{\multicolumn{2}{|c|}{ Construct }} & & \multicolumn{7}{|c|}{ In Percent $(1=$ Totally Agree to $7=$ Totally Disagree $)$} & \multirow{3}{*}{$\begin{array}{c}\text { Mean } \\
3.33\end{array}$} & \multirow{3}{*}{$\begin{array}{c}\text { Std. dev. } \\
1.748\end{array}$} \\
\hline & & & \multirow{2}{*}{$\begin{array}{c}\mathbf{1} \\
17.5\end{array}$} & \multirow{2}{*}{$\begin{array}{c}2 \\
18.4\end{array}$} & \multirow{2}{*}{$\begin{array}{c}3 \\
23.5\end{array}$} & \multirow{2}{*}{$\begin{array}{c}4 \\
15.6\end{array}$} & \multirow[b]{2}{*}{9.5} & \multirow{2}{*}{$\begin{array}{c}\mathbf{6} \\
10.8\end{array}$} & \multirow{2}{*}{$\begin{array}{c}7 \\
4.8\end{array}$} & & \\
\hline EAGC [21] & V1.1 & $\begin{array}{l}\text { I actively search for possibilities to buy from local farmers (on farmers' } \\
\text { markets, directly at farmers). }\end{array}$ & & & & & & & & & \\
\hline & V1.2 & I am quite cautious when buying fish and prefer to pay more for organic fish. & 34.9 & 25.1 & 14.3 & 10.2 & $\begin{array}{l}8.9 \\
197\end{array}$ & 4.8 & $\begin{array}{l}1.9 \\
48\end{array}$ & $\begin{array}{l}2.55 \\
3.78\end{array}$ & 1.626 \\
\hline & V1.4 & $\begin{array}{l}\text { I pay attention to pesticide-free production of vegetables (no use } \\
\text { of pesticides). }\end{array}$ & 30.5 & 22.9 & 14.3 & 13.3 & 6.7 & 7.9 & 4.4 & 2.84 & 1.805 \\
\hline & V1.5 & $\begin{array}{l}\text { If the price for organic produce is much higher (e.g., more than } 50 \% \text { plus) } \\
\text { compared to conventional food, I decide to purchase the conventional food. }\end{array}$ & 13.3 & 7.9 & 13.3 & 15.6 & 19.7 & 20.3 & 9.8 & 4.21 & 1.875 \\
\hline & V1.6 & $\begin{array}{l}\text { When buying food in super markets, I prefer to buy regional food even if it } \\
\text { is more expensive. }\end{array}$ & 27.9 & 35.6 & 21.3 & 6.0 & 6.0 & 1.3 & 1.9 & 2.38 & 1.348 \\
\hline \multirow[t]{6}{*}{ AA [60] } & V4.1 & $\begin{array}{l}\text { If aquaponic produce is offered in a shop at a reasonable price, I think } \\
\text { I would buy it. }\end{array}$ & 39.7 & 33.3 & 15.9 & 7.9 & 1.3 & 0.6 & 1.3 & 2.05 & 1.187 \\
\hline & V4.2 & I consider aquaponic produce to make sense. & 45.1 & 29.2 & 15.6 & 7.6 & 1.6 & 0.0 & 1.0 & 1.95 & 1.137 \\
\hline & V4.3 & My overall evaluation of aqua ponic produce is positive. & 36.8 & 33.7 & 16.8 & 8.9 & 1.6 & 1.0 & 1.3 & 2.13 & 1.222 \\
\hline & V4.4 & I think aquaponic produce is very good. & 31.4 & 28.6 & 21.9 & 14.3 & 1.6 & 1.0 & 1.3 & 2.34 & 1.268 \\
\hline & V4.5 & Aquaponic produce supports the conservation of the sea. & 46.0 & 21.6 & 16.2 & 11.4 & 1.0 & 1.9 & 1.9 & 2.13 & 1.391 \\
\hline & V4.6 & Aquaponics delivers answers for sustainable food production. & 43.5 & 26.3 & 16.2 & 9.2 & 2.2 & 1.3 & 1.3 & 2.09 & 1.297 \\
\hline \multirow[t]{3}{*}{ PI [21] } & V5.1 & $\begin{array}{l}\text { If I have to decide between aquaponic vegetables and con ventional } \\
\text { vegetables, I will buy the aquaponic vegetables. }\end{array}$ & 19.0 & 24.8 & 29.2 & 20.6 & 2.9 & 1.9 & 1.6 & 2.76 & 1.304 \\
\hline & V5.4 & $\begin{array}{l}\text { If I have to decide between aqua ponic fish and conventional fish, I will buy } \\
\text { the aquaponic fish. }\end{array}$ & 27.6 & 28.6 & 20.6 & 17.1 & 3.5 & 1.3 & 1.3 & 2.49 & 1.329 \\
\hline & V5.5 & I would purchase aquaponic vege tables even though it is more expensive. & 17.1 & 27.3 & 31.4 & 13.3 & 6.7 & 2.2 & 1.9 & 2.79 & 1.352 \\
\hline \multirow[t]{4}{*}{ WTP [61] } & V6.1 & $\begin{array}{l}\text { I am willing to buy aquaponic produce even though the range of products } \\
\text { is limited. }\end{array}$ & 21.9 & 27.3 & 31.7 & 13.3 & 3.2 & 1.6 & 1.0 & 2.57 & 1.235 \\
\hline & V6.2 & I am willing to buy aquaponic pro duce as benefits outbalance cost. & 14.9 & 30.2 & 28.9 & 18.1 & 4.1 & 2.5 & 1.3 & 2.79 & 1.28 \\
\hline & V6.3 & $\begin{array}{l}\text { For me, purchasing aquaponic produce is the right thing even though it is } \\
\text { more expensive. }\end{array}$ & 13.3 & 28.6 & 29.2 & 17.8 & 7.0 & 2.5 & 1.6 & 2.9 & 1.325 \\
\hline & V6.4 & I don't mind investing more time in purchasing aquaponic produce. & 7.3 & 15.9 & 28.3 & 21.0 & 14.0 & 8.9 & 4.8 & 3.64 & 1.542 \\
\hline
\end{tabular}


Table A2. Construct Familiarity: Frequencies.

\begin{tabular}{lcccc}
\hline \multicolumn{2}{c}{ Construct } & & \multicolumn{2}{c}{ In Percent } \\
& & & $\mathbf{1}=$ yes & $\mathbf{2}=$ no \\
\hline FA $[10,21]$ & V1.1 & Have you ever heard of aquaponics? & 12.4 & 87.6 \\
\hline
\end{tabular}

\section{References}

1. FAO. Feeding People, Protecting the Planet; FAO: Rome, Italy, 2018; Available online: http://www.fao.org/3/ CA0130EN/ca0130en.pdf (accessed on 8 January 2020).

2. FAO. The State of World Fisheries and Aquaculture 2016; FAO: Rome, Italy, 2016; Available online: http: //www.fao.org/3/a-i5555e.pdf (accessed on 8 January 2020).

3. United Nations, Department of Economic and Social Affairs, Population Division. World Population Prospects 2019; United Nations: New York, NY, USA, 2019.

4. FAO. Proceedings of the Expert Meeting on How to Feed the World in 2050; FAO: Rome, Italy, 2009; Available online: http://www.fao.org/3/ak542e/ak542e00.pdf (accessed on 8 January 2020).

5. FAO. Building a Common Vision for Sustainable Food and Agriculture; FAO: Rome, Italy, 2014.

6. Junge, R.; König, B.; Villarroel, M.; Komives, T.; Jijakli, M. Strategic Points in Aquaponics. Water 2017, 9, 182. [CrossRef]

7. Somerville, C.; Cohen, M.; Pantanella, E.; Stankus, A.; Lovatelli, A. Small-Scale Aquaponic Food Production. Integrated Fish and Plant Farming; FAO Fisheries and Aquaculture Technical Paper; FAO: Rome, Italy, 2014; Volume 589.

8. Asciuto, A.; Schimmenti, E.; Cottone, C.; Borsellino, V. A financial feasibility study of an aquaponic system in a Mediterranean urban context. Urban. For. Urban. Green. 2019, 38, 397-402. [CrossRef]

9. Yep, B.; Zheng, Y. Aquaponic trends and challenges-A review. J. Clean. Prod. 2019, 228, 1586-1599. [CrossRef]

10. Greenfeld, A.; Becker, N.; Bornman, J.F.; Dos Santos, M.J.; Angel, D. Consumer preferences for aquaponics: A comparative analysis of Australia and Israel. J. Environ. Manag. 2020, 257, 109979. [CrossRef]

11. Goddek, S.; Delaide, B.; Mankasingh, U.; Ragnarsdottir, K.; Jijakli, H.; Thorarinsdottir, R. Challenges of Sustainable and Commercial Aquaponics. Sustainability 2015, 7, 4199-4224. [CrossRef]

12. Graber, A.; Junge, R. Aquaponic Systems: Nutrient recycling from fish wastewater by vegetable production. Desalination 2009, 246, 147-156. [CrossRef]

13. dos Santos, M.J.P.L. Smart cities and urban areas-Aquaponics as innovative urban agriculture. Urban. For. Urban. Green. 2017, 20, 402-406. [CrossRef]

14. Hindelang, M.; Gheewala, S.H.; Mungkung, R.; Bonnet, S. Environmental sustainability assessment of a media based aquaponics system in Thailand. J. Sustain. Energy Environ. 2014, 5, 109-116.

15. Laidlaw, J.; Magee, L. Towards urban food sovereignty: The trials and tribulations of community-based aquaponics enterprises in Milwaukee and Melbourne. Local Environ. 2014, 21, 573-590. [CrossRef]

16. Nichols, M.A.; Savidov, N.A. Aquaponics: Protein and vegetables for developing countries. In Proceedings of the International Symposium on Sustainable Vegetable Production in Southeast Asia, Salatiga, Indonesia, 31 August 2011; Volume 958, pp. 189-193.

17. Bernstein, S. Aquaponic Gardening: A Step-by-Step Guide to Raising Vegetables and Fish Together; New Society Publishers: Gabriola Island, BC, Canada, 2011.

18. Nichols, M.A.; Savidov, N.A. Aquaponics: A nutrient and water efficient production system. Acta Hortic. 2012, 129-132. [CrossRef]

19. Villarroel, M.; Junge, R.; Komives, T.; König, B.; Plaza, I.; Bittsánszky, A.; Joly, A. Survey of Aquaponics in Europe. Water 2016, 8, 468. [CrossRef]

20. Love, D.C.; Fry, J.P.; Genello, L.; Hill, E.S.; Frederick, J.A.; Li, X.; Semmens, K. An international survey of aquaponics practitioners. PLoS ONE 2014, 9, e102662. [CrossRef] [PubMed]

21. Miličić, V.; Thorarinsdottir, R.; Santos, M.; Hančič, M. Commercial Aquaponics Approaching the European Market: To Consumers' Perceptions of Aquaponics Products in Europe. Water 2017, 9, 80. [CrossRef]

22. AMA-Marketing. Bio Landwirtschaft in Österreich. Available online: http://bioinfo.at/bioinfo-biolandwirtschaft-in-oesterreich (accessed on 15 April 2020). 
23. Tokunaga, K.; Tamaru, C.; Ako, H.; Leung, P. Economics of small-scale commercial aquaponics in Hawai'i. J. World Aquac. Soc. 2015, 46, 20-32. [CrossRef]

24. Turnšek, M.; Morgenstern, R.; Schröter, I.; Mergenthaler, M.; Hüttel, S.; Leyer, M. Commercial Aquaponics: A Long Road Ahead. In Aquaponics Food Production Systems, 1st ed.; Goddek, S., Joyce, A., Kotzen, B., Burnell, G.M., Eds.; Springer International Publishing: Cham, Switzerland, 2019; pp. 453-485.

25. Van Gorcum, B.; Goddek, S.; Keesman, K.J. Gaining market insights for aquaponically produced vegetables in Kenya. Aquacult. Int. 2019, 27, 1231-1237. [CrossRef]

26. Blidariu, F.; Grozea, A. Increasing the Economical Efficiency and Sustainability of Indoor Fish Farming by Means of Aquaponics-Review. Anim. Sci. Biotechnol. 2011, 1-8.

27. Bosma, R.H.; Lacambra, L.; Landstra, Y.; Perini, C.; Poulie, J.; Schwaner, M.J.; Yin, Y. The financial feasibility of producing fish and vegetables through aquaponics. Aquacult. Eng. 2017, 78, 146-154. [CrossRef]

28. Specht, K.; Weith, T.; Swoboda, K.; Siebert, R. Socially acceptable urban agriculture businesses. Agron. Sustain. Dev. 2016, 36, 131. [CrossRef]

29. Tyson, R.V.; Treadwell, D.D.; Simonne, E.H. Opportunities and Challenges to Sustainability in Aquaponic Systems. HortTechnology 2011, 21, 6-13. [CrossRef]

30. Zugravu, A.G.; Rahoveanu, M.M.T.; Rahoveanu, A.T.; Khalel, M.S.; Ibrahim, M.A.R. The Perception of Aquaponics Products in Romania. In Proceedings of the International Conference "Risk in Contemporary Economy," Faculty of Economics and Business Administration, Galati, Romania, 26-27 October 2016; pp. 1-6.

31. Tamin, M.; Harun, A.; Estim, A.; Saufie, S.; Obong, S. Consumer Acceptance towards Aquaponic Products. J. Bus. Manag. 2015, 49-64. [CrossRef]

32. Pollard, G.; Ward, J.D.; Koth, B. Aquaponics in Urban Agriculture: Social Acceptance and Urban Food Planning. Horticulturae 2017, 3, 39. [CrossRef]

33. Hoch, S.J.; Deighton, J. Managing What Consumers Learn from Experience. J. Market. 1989, 53, 1-20. [CrossRef]

34. Park, C.W.; Mothersbaugh, D.L.; Feick, L. Consumer Knowledge Assessment. J. Consum. Res. 1994, $21,71$. [CrossRef]

35. Chan, R.Y.K. Determinants of Chinese consumers' green purchase behavior. Psychol. Market. 2001, $389-413$. [CrossRef]

36. Hoffmann, S.; Akbar, P. Konsumentenverhalten: Konsumenten Verstehen-Marketingmaßnahmen Gestalten; Springer Fachmedien: Wiesbaden, Germany, 2016.

37. Monhemius, K.C. Umweltbewußtes Kaufverhalten von Konsumenten; Peter Lang: Bern, Switzerland, 1993.

38. Mostafa, M.M. A hierarchical analysis of the green consciousness of the Egyptian consumer. Psychol. Market. 2007, 24, 445-473. [CrossRef]

39. Peattie, K.J. Green Marketing; Pitman: London, UK, 1992.

40. Schaffner, D.; Metzger, B.; Michel, S. Konsumentenverhalten; Versus Verlag: Zürich, Switzerland, 2011.

41. Schiffman, L.G.; Kanuk, L.L. Consumer Behavior, 9th ed.; Pearson Prentice Hall: Upper Saddle River, NJ, USA, 2007.

42. Kroeber-Riel, W.; Gröppel-Klein, A. Konsumentenverhalten; Vahlen: Munich, Germany, 2013.

43. Barber, N.; Taylor, C.; Strick, S. Wine consumers' environmental knowledge and attitudes: Influence on willingness to purchase. Int. J. Wine Res. 2009, 59-72. [CrossRef]

44. Hartmann, P.; Apaolaza-Ibáñez, V. Consumer attitude and purchase intention toward green energy brands: The roles of psychological benefits and environmental concern. J. Bus. Res. 2012, 65, 1254-1263. [CrossRef]

45. Kozup, J.C.; Creyer, E.H.; Burton, S. Making Healthful Food Choices: The Influence of Health Claims and Nutrition Information on Consumers' Evaluations of Packaged Food Products and Restaurant Menu Items. J. Market. 2003, 67, 19-34. [CrossRef]

46. Ajzen, I. The Theory of Planned Behavior. Organ. Behav. Hum. Dec. 1991, 179-211. [CrossRef]

47. Gafni, A. Willingness To Pay: What's in a Name? Pharmacoeconomics 1998, 465-470. [CrossRef]

48. Bower, J.A.; Saadat, M.A.; Whitten, C. Effect of liking, information and consumer characteristics on purchase intention and willingness to pay more for a fat spread with a proven health benefit. Food Qual. Pref. 2003, 14, 65-74. [CrossRef]

49. Zhang, B.; Fu, Z.; Huang, J.; Wang, J.; Xu, S.; Zhang, L. Consumers' perceptions, purchase intention, and willingness to pay a premium price for safe vegetables: A case study of Beijing, China. J. Clean. Prod. 2018, 197, 1498-1507. [CrossRef] 
50. Xu, P.; Zeng, Y.; Fong, Q.; Lone, T.; Liu, Y. Chinese consumers' willingness to pay for green- and eco-labeled seafood. Food Control. 2012, 28, 74-82. [CrossRef]

51. Chen, A.; Peng, N. Green hotel knowledge and tourists' staying behavior. Ann. Tour. Res. 2012, 39, 2211-2216. [CrossRef]

52. Mollá-Bauza, M.M.B.; Martínez, L.M.-C.; Poveda, A.M.; Pérez, M.R. Determination of the surplus that consumers are willing to pay for an organic wine. Span. J. Agricult. Res. 2005, 43-51. [CrossRef]

53. Makatouni, A. What motivates consumers to buy organic food in the UK? Brit. Food J. 2002, 104, $345-352$. [CrossRef]

54. Smith, S.; Paladino, A. Eating clean and green? Investigating consumer motivations towards the purchase of organic food. Australasian Market. J. (AMJ) 2010, 18, 93-104. [CrossRef]

55. Jaiswal, D.; Kant, R. Green purchasing behaviour: A conceptual framework and empirical investigation of Indian consumers. J. Retail. Consum. Serv. 2018, 41, 60-69. [CrossRef]

56. Sekaran, U. Research Methods for Business: A Skill-Building Approach, 3rd ed.; John Wiley \& Sons: New York, NY, USA, 2000.

57. Kinnear, T.C.; Taylor, J.R. Marketing Research: An Applied Approach, 5th ed.; McGraw-Hill: New York, NY, USA, 1996.

58. Hair, J.F.; Anderson, R.E.; Tatham, R.L.; Black, W.C. Multivariate Data Analysis; Prentice Hall: Upper Saddle River, NJ, USA, 1998.

59. Kline, R.B. Principles and Practice of Structural Equation Modeling, 2nd ed.; Guildford: New York, NY, USA, 2005.

60. Ratneshwar, S.; Chaiken, S. Comprehension's Role in Persuasion: The Case of Its Moderating Effect on the Persuasive Impact of Source Cues. J. Consum. Res. 1991, 52-62. [CrossRef]

61. Voon, J.P.; Ngui, K.S.; Agrawal, A. Determinants of Willingness to Purchase Organic Food: An Exploratory Study Using Structural Equation Modeling. Int. Food Agribus. Manag. 2011, 14, 103-120.

62. Iacobucci, D. Everything you always wanted to know about SEM (structural equations modeling) but were afraid to ask. J. Consum. Psychol. 2009, 19, 673-680. [CrossRef]

63. Baumgartner, H.; Homburg, C. Applications of structural equation modeling in marketing and consumer research: A Review. Int. J. Res. Market. 1996, 139-161. [CrossRef]

64. Schumacker, R.E.; Lomax, R.G. A Beginner's Guide to Structural Equation Modeling; Psychology Press: Hove, UK, 2004.

65. Homburg, C.; Giering, A. Konzeptualisierung und Operationalisierung komplexer Konstrukte. Ein Leitfaden für die Marketingforschung. Marketing-ZFP 1996, 18, 5-24. [CrossRef]

66. Kaiser, H.F.; Rice, J. Little Jiffy, Mark Iv. Educ. Psychol. Meas. 1974, 34, 111-117. [CrossRef]

67. Hair, J.F.; Babin, B.J.; Anderson, R.E.; Black, W.C. Multivariate Data Analysis, 7th ed.; Pearson new international edition; Pearson: Essex, UK, 2014.

68. Weiber, R.; Mühlhaus, D. Strukturgleichungsmodellierung-Eine anwendungsorientierte Einführung in die Kausalanalyse mit Hilfe von AMOS, SmartPLS und SPSS, 2nd ed.; Springer Verlag: Berlin/Heidelberg, Germany, 2014.

69. Bagozzi, R.P.; Baumgartner, H. The evaluation of structural equation models and hypotheses testing. Prin. Market. Res. 1994, 386-422.

70. Bagozzi, R.P.; Yi, Y. On the evaluation of structural equation models. J. Acad. Market. Sci. 1988, 16, 74-94. [CrossRef]

71. Fornell, C.; Larcker, D.F. Evaluating Structural Equation Models with Unobservable Variables and Measurement Error. J. Market. Res. 1981, 18, 39. [CrossRef]

72. Peter, J.P. Construct Validity: A Review of Basic Issues and Marketing Practices. J. Market. Res. 1981, 18, 133-145. [CrossRef]

73. Browne, M.W.; Cudeck, R. Alternative ways of assessing equation model fit. In Testing Structural Equation Models; Bollen, K.A., Long, J.S., Eds.; Sage: Newbury Park, CA, USA, 1993; pp. 136-162.

74. Bentler, P. Comparative Fit Indexes in Structural Models. Psychol. Bull. 1990, 238-246. [CrossRef]

75. Bollen, K.A. Structural Equations with Latent Variables; Wiley-Interscience: New York, NY, USA, 1989.

76. Homburg, C.; Baumgartner, H. Beurteilung von Kausalmodellen. Bestandsaufnahme und Anwendungsempfehlungen. Marketing-ZFP 1995, 17, 162-176. [CrossRef]

77. Henseler, J. Einführung in die PLS-Pfadmodellierung. WIST 2005, 34, 70-75. [CrossRef] 
78. Fornell, C.; Cha, J. Partial least squares. In Advanced Methods of Marketing Research; Bagozzi, R.P., Ed.; Blackwell Business: Oxford, UK, 1994; pp. 52-78.

79. Yadav, R.; Pathak, G.S. Young consumers' intention towards buying green products in a developing nation: Extending the theory of planned behavior. J. Clean. Prod. 2016, 135, 732-739. [CrossRef]

80. Mostafa, M.M. Antecedents of Egyptian Consumers' Green Purchase Intentions. J. Int. Consum. Market. 2006, 19, 97-126. [CrossRef]

81. Paul, J.; Modi, A.; Patel, J. Predicting green product consumption using theory of planned behavior and reasoned action. J. Retail. Consum. Serv. 2016, 29, 123-134. [CrossRef]

82. Honkanen, P.; Verplanken, B.; Olsen, S.O. Ethical values and motives driving organic food choice. J. Consum. Behav. 2006, 5, 420-430. [CrossRef]

83. Lai, C.K.M.; Cheng, E.W.L. Green purchase behavior of undergraduate students in Hong Kong. Soc. Sci. J. 2016, 53, 67-76. [CrossRef]

84. Kumar, B.; Manrai, A.K.; Manrai, L.A. Purchasing behaviour for environmentally sustainable products: A conceptual framework and empirical study. J. Retail. Consum. Serv. 2017, 34, 1-9. [CrossRef]

85. Wei, C.-F.; Chiang, C.-T.; Kou, T.-C.; Lee, B.C.Y. Toward Sustainable Livelihoods: Investigating the Drivers of Purchase Behavior for Green Products. Bus. Strat. Env. 2017, 26, 626-639. [CrossRef]

86. Mitchell, R.C.; Carson, R.T. Using Surveys to Value Public Goods: The Contingent Valuation Method; Resource for the Future: Washington, DC, USA, 1989.

87. Whittington, D.; Lauria, D.T.; Mu, X. A study of water vending and willingnessto pay for water in Onitsha, Nigeria. World Dev. 1991, 19, 79-98. [CrossRef]

(C) 2020 by the authors. Licensee MDPI, Basel, Switzerland. This article is an open access article distributed under the terms and conditions of the Creative Commons Attribution (CC BY) license (http://creativecommons.org/licenses/by/4.0/). 